\title{
Comparative Response of Cabbage to Irrigation in Southern Malawi
}

\author{
Davie Mayeso Kadyampakeni ${ }^{1,2}$ \\ ${ }^{1}$ Kasinthula Research Station, Chikwawa, Malawi \\ ${ }^{2}$ Southwest Florida Research and Education Center, University of Florida, United States \\ Correspondence: Davie Mayeso Kadyampakeni, Southwest Florida Research and Education Center, University of \\ Florida, 2685 SR 29 N, Immokalee, FL 34142, United States. Tel: 265-239-658-3400, E-mail: \\ dakadyampakeni@yahoo.com
}

Received: March 18, 2013 Accepted: May 20, 2013 Online Published: July 15, 2013

doi:10.5539/jas.v5n8p1 URL: http://dx.doi.org/10.5539/jas.v5n8p1

\begin{abstract}
An experiment was conducted at Kasinthula and Masenjere in Chikwawa district in Malawi in the dry seasons (May through August) of 2006 and 2007 to evaluate yield response of cabbage (Brassica oleraceae) to irrigation frequency. The study was laid out in a randomized complete block design (RCBD) where three irrigation frequencies served as treatments: F1-Irrigated twice a week, F2-Irrigated once a week and F3-Irrigated once a fortnight. At Kasinthula, weight of marketable heads and water-use efficiency (WUE) were significantly different $(\mathrm{P}<0.05)$ across the irrigation frequencies. At Kasinthula and Masenjere, F1 resulted in highest yield of 32.9 and $23.0 \mathrm{t} \mathrm{ha}^{-1}$ in 2006 and 2007 seasons. There was a 50\% and $25 \%$ reduction in yield in 2007 at Kasinthula and Masenjere Research sites. WUE peaked in F1 to 83.6 and $57.5 \mathrm{~kg} \mathrm{ha}^{-1} \mathrm{~mm}^{-1}$ in 2006 and 2007 while lowest values were noted using F3 resulting in WUE of 57.9 and $39.4 \mathrm{~kg} \mathrm{ha}^{-1} \mathrm{~mm}^{-1}$. Water productivity (WP) was significantly different across irrigation frequency $(\mathrm{P}<0.05)$. F3 resulted in the highest WP of 11.8 and $7.4 \mathrm{~kg} \mathrm{~m}^{-3}$ in 2006 and 2007, respectively. The lowest WP of 6.7 and $5.2 \mathrm{~kg} \mathrm{~m}^{-3}$ were observed in $\mathrm{F} 1$ in the two years. Comparing all the irrigation frequencies, F3 turns out to be the most effective water saving irrigation frequency suggesting that in the face of competing water needs and dwindling water resources, the longer duration F3 irrigation frequency is preferred to shorter duration ones. Where water is considered ample, F1 is recommended.
\end{abstract}

Keywords: irrigation frequency, furrow irrigation, water productivity, water-use efficiency

\section{Introduction}

Vegetables are an important source of vitamins and mineral which are vital for good health. Despite being widely grown in Malawi, adequate supplies of vegetables are mostly available in the rainy season (November through April) yearly. Consequently, supplies are not adequate throughout the year especially in semi-arid areas of the country. By increasing water productivity in vegetable production, irrigated agriculture may increase substantially (FAO, 2000; Rockstrom et al., 2002). Smith (2000) reported that genetic characteristics of a crop are the primary factors determining water use productivity because they determine assimilation characteristics, the respiration and physiological processes that convert the assimilates into biomass and harvest index which partitions biomass into the harvestable product and non-useful product. Doorenbos and Kassam (1979) categorized crops according to their yield response to water namely: crops sensitive to water stress and those tolerant to drought. They observed that the crops are self-exclusive, meaning that high producing crops which can obtain high water productivity are highly sensitive to water stress, while stress tolerant crops can still achieve yields under water stress but do not attain the high yield and water use under optimal water supply, ceteris paribus.

The amount of water required by plants and the timing of irrigation are governed by prevailing climatic conditions, crop and stage of growth, soil moisture holding capacity and the extent of root development as determined by crop type, stage of growth and soil. Thus, the amount of water required by plants varies from place to place. For practical purposes, it is important to determine the relationship between yield and water in a given locality in a simplified form because the relationship is intrinsically complex (Doorenbos \& Kassam, 1979) as it is affected by factors other than water such as crop variety, salinity, pests and diseases, and agronomic practices. Better irrigation management after determination of yield response could help in maximizing WUE 
and avoiding long-term build-up of salinity and soil degradation (Hess \& Molatakgosi, 2009). Also, improved water management would help in coping with increasing demands for water by industrial and urban users and the agricultural sector (de Fraiture \& Wichelns, 2010) thereby making water available for environmental and other uses (de Fraiture et al., 2010). De Fraiture et al. (2010) advocate for a fresh look at approaches that combine different elements such as the importance of adapting irrigation to new needs, enhancing water productivity, and promoting the use of low-quality water in agriculture. Several researchers observe that there are sufficient land and water resources available to satisfy global food demands during the next 50 years, but only if water is managed more effectively in agriculture.

In Malawi, no study has been conducted recently on vegetables such as cabbage to ascertain the crop's response to various irrigation regimes. It is important that on-farm and/or on-station water management studies are conducted on vegetables under various irrigation schedules and frequencies to determine water use patterns and yields for efficient irrigation management. This explains the need for irrigated vegetable production to meet both subsistence needs of farmers and their commercial objectives. Also, through schedules developed in the studies, it will be possible to provide resource-poor farmers in semi-arid areas of Malawi with options for supplementary irrigation in summer (rainy season) and full irrigation in winter (dry season). Improved irrigation management appears to be the panacea to increased cabbage availability and production in Malawi.

The experiment was conducted to evaluate yield, water-use efficiency and productivity of cabbage under three irrigation frequencies. It was hypothesized that irrigation frequency does not have any significant impact on cabbage yield, water-use efficiency and water productivity.

\section{Method}

\subsection{Study Sites}

The experiment was conducted at Kasinthula and Masenjere in Chikwawa District in southern Malawi. Kasinthula lies at $16^{\circ} \mathrm{S} 34^{\circ} 5^{\prime} \mathrm{E}$ at $60 \mathrm{~m}$ above sea level (a.s.l.) (Fandika et al., 2007) while Masenjere is located at $16^{\circ} 20^{\prime} \mathrm{S}, 35^{\circ} 6^{\prime} \mathrm{E}$, approximately 93 a.s.l (Poynton, 1995). The soil at Kasinthula Research Station is Kapasule series, provisionally classified as aquic Hapslustalf (Barak, 1986) in the order Alfisols. The surface horizon is loamy sand while the subsurface horizon is sandy clay loam. It is moderately coarse to moderately fine textured developed in the brown sediments of the lower Shire terrace. The soil is moderately drained with a water table at $2.5 \mathrm{~m}$ from the ground surface. The available was estimated to be $100 \mathrm{~mm} \mathrm{~m}^{-1}$ (Chilimba, 1990). Soil physical and chemical characteristics for Kasinthula and Masenjere are presented in Table 1.

The average climatic conditions of Kasinthula Experiment Research Station monthly total rainfall ( $\mathrm{mm}$ ), average maximum and minimum temperature $\left({ }^{\circ} \mathrm{C}\right)$, relative humidity $(\%)$, wind speed $\left(\mathrm{km} \mathrm{hr}^{-1}\right)$, sunshine hours $\left(\mathrm{h} \mathrm{d}^{-1}\right)$, solar radiation (Langley), and monthly total evaporation $(\mathrm{mm})$ are presented in Table 2 below. Masenjere research site receives average annual rainfall of $860 \mathrm{~mm}$. The soil is a deep, colluvial sandy loam (Poynton, 1995).

Table 1. Average soil characteristics at Kasinthula and Masenjere

\begin{tabular}{cccccccccccc}
\hline $\begin{array}{c}\text { Soil depth } \\
(\mathrm{cm})\end{array}$ & $\begin{array}{c}\text { Sand } \\
(\%)\end{array}$ & $\begin{array}{c}\text { Silt } \\
(\%)\end{array}$ & $\begin{array}{c}\text { Clay } \\
(\%)\end{array}$ & $\begin{array}{c}\text { Textural } \\
\text { class }\end{array}$ & $\begin{array}{c}\text { FC } \\
(\%)\end{array}$ & $\begin{array}{c}\text { PWP } \\
(\%)\end{array}$ & $\begin{array}{c}\text { Available water } \\
(\%)\end{array}$ & $\begin{array}{c}\text { Bulk density } \\
\left(\mathrm{g} / \mathrm{cm}^{3}\right)\end{array}$ & $\begin{array}{c}\mathrm{pH} \\
(\mathrm{water})\end{array}$ & $\begin{array}{c}\mathrm{N} \\
(\mathrm{mg} / \mathrm{kg})\end{array}$ & $\begin{array}{c}\mathrm{P} \\
(\mathrm{mg} / \mathrm{kg})\end{array}$ \\
\hline $0-30$ & 75 & 7 & 18 & LS & 10.27 & 5.65 & 4.62 & 1.67 & 6.44 & 6.0 & 24 \\
$30-60$ & 74 & 7 & 19 & LS & 12.34 & 5.98 & 6.4 & 1.71 & 6.66 & 6.0 & 25 \\
$60-90$ & 74 & 6 & 20 & SCL & 13.75 & 6.69 & 7.06 & 1.69 & 6.57 & 5.0 & 25 \\
\hline & & & & & & Masenjere & & ND & 6.98 & 1.0 & 10 \\
$30-30$ & 70 & 6 & 24 & SCL & ND & ND & ND & ND & 7.03 & 1.0 & 13 \\
$60-90$ & 76 & 10 & 16 & SL & ND & ND & ND & ND & 7.02 & 3.0 & 16 \\
\hline
\end{tabular}

Notes: FC-Field capacity moisture content, PWP-Permanent wilting point, ND-Not determined. 
Table 2. Meteorological data during the dry seasons at Kasinthula in 2006 and 2007

\begin{tabular}{|c|c|c|c|c|c|c|}
\hline \multirow{2}{*}{ Weather variable } & \multicolumn{6}{|c|}{2006} \\
\hline & May & June & July & August & September & October \\
\hline Average maximum temperature $\left({ }^{\circ} \mathrm{C}\right)$ & 33.4 & 29.2 & 28.9 & 29.7 & 33.6 & 35.3 \\
\hline Average minimum temperature $\left({ }^{\circ} \mathrm{C}\right)$ & 18.3 & 15.0 & 12.7 & 17.5 & 21.5 & 22.0 \\
\hline Average relative humidity (\%) & 64.0 & 68.2 & 71.3 & 64.0 & 57.4 & 78.4 \\
\hline Average wind speed $\left(\mathrm{km} \mathrm{h}^{-1}\right)$ & 3.7 & 3.4 & 2.2 & 2.9 & 5.9 & 4.6 \\
\hline Average sunshine hours $\mathrm{d}^{-1}$ & 7.8 & 7.7 & 7.7 & 9.7 & 9.0 & 9.1 \\
\hline Total rainfall, $\mathrm{mm}$ & 0.2 & 0.3 & 0.0 & 0.0 & 0.0 & 0.0 \\
\hline Average solar radiation (Langley) & 476.0 & 453.0 & 474.0 & 512.0 & 537.0 & 573.0 \\
\hline \multirow[t]{2}{*}{ Average pan evaporation $\left(\mathrm{mm} \mathrm{d}^{-1}\right)$} & 4.6 & 4.3 & 4.7 & 6.4 & 7.9 & 9.7 \\
\hline & \multicolumn{6}{|c|}{2007} \\
\hline Average maximum temperature $\left({ }^{\circ} \mathrm{C}\right)$ & 30 & 26.5 & 22 & 31.9 & 34.7 & 35.6 \\
\hline Average minimum temperature $\left({ }^{\circ} \mathrm{C}\right)$ & 17 & 14.1 & 13 & 13.3 & 15.6 & 19.8 \\
\hline Average relative humidity (\%) & 81 & 91 & 71 & 89.6 & 92.2 & 72 \\
\hline Average wind speed $\left(\mathrm{km} \mathrm{h}^{-1}\right)$ & 7 & 8.9 & 11 & 11.9 & 16.1 & 19.2 \\
\hline Average sunshine hours $\mathrm{d}^{-1}$ & 8 & 8.5 & 8 & 8.9 & 9.7 & 9.9 \\
\hline Total rainfall, $\mathrm{mm}$ & 4.9 & 5.1 & 45.2 & 6.4 & 0 & 14 \\
\hline Average solar radiation (Langley) & - & - & - & - & - & - \\
\hline Average pan evaporation $\left(\mathrm{mm} \mathrm{d}^{-1}\right)$ & 4.9 & 5 & 3.8 & 5.4 & 7.2 & 8.9 \\
\hline
\end{tabular}

\subsection{Experimental Design and Treatments}

Irrigation frequencies constituted the treatments in the study namely: F1-Irrigated twice a week, F2-Irrigated once a week, and F3-Irrigated once bi-weekly. All treatments were replicated four times, in plots $5 \mathrm{~m}$ by $5 \mathrm{~m}$, where $1 \mathrm{~m}$ was left on each side as a buffer for gravimetric soil moisture determination and routine measurements. Plants, cabbage variety Giant drumhead, were planted at $0.6 \mathrm{~m}$ in between and within rows.

\subsection{Fertilizer and Water Application}

Calcium Ammonium Nitrate (CAN), an inorganic fertilizer was applied at the rate of $100 \mathrm{~kg} \mathrm{~N} \mathrm{ha}^{-1}$ by banding. Irrigation water was applied in 5-m long furrows using a gated 10-cm diameter PVC pipe. Each gate was set at a flow rate of 30 litres per minute. The flow rate out of each gate was determined using a calibrated bucket. The PVC pipe was laid at the beginning of the furrows, and connected to a concrete lined canal in which water level was maintained at a constant head above the center of the PVC pipe inlet.

\subsection{Irrigation Scheduling}

The experimental plots were irrigated to field capacity at planting and irrigation schedules were imposed four weeks after planting. The soil moisture storage was estimated from available water holding capacity of $100 \mathrm{~mm}$ $\mathrm{m}^{-1}$ and the crop root zone. The crop consumptive use was computed from climatic data using the evaporation pan method for estimating reference evapotranspiration (ETo). The ETo was calculated daily and then multiplied by the cabbage crop coefficient (Kc) (Table 3) at a particular growth stage to determine the consumptive water use based on well established procedures (Doorenbos \& Pruitt, 1977; Doorenbos \& Kassam, 1979; 1986; Allen et al., 1998), according to the following equation:

$$
\mathrm{ETC}=\mathrm{Kc} * \text { ETo }
$$

Where ETc is crop consumptive water use $(\mathrm{mm})$.

The equation for estimating crop WUE ( $\mathrm{kg} \mathrm{ha}^{-1} \mathrm{~mm}^{-1}$ ) according to Kirda (2002) and Lovelli et al. (2007) is:

$$
\mathrm{WUE}=\frac{\mathrm{Y}}{\mathrm{ETa}}
$$

Where $\mathrm{Y}$ is crop yield $\left(\mathrm{kg} \mathrm{ha}^{-1}\right)$ and ETa is actual evapotranspiration $(\mathrm{mm})$ which was regarded as crop evapotranspiration (mm), in this study.

Water productivity (WP in $\mathrm{kg} \mathrm{m}^{-3}$ ) according to Smith (2000) is given by the following expression: 


$$
\mathrm{WP}=\frac{\mathrm{Y}}{\mathrm{TWA}}
$$

Where TWA is total water applied (mm).

Table 3. Crop coefficients (Kc) for cabbage at various growth stages

\begin{tabular}{ccc}
\hline Growth stage & Crop coefficient, Kc & Days after planting (DAP) \\
\hline Initial stage & 0.45 & 1 \\
Crop development stage & 0.75 & 22 \\
Mid-season stage & 1.05 & 48 \\
Late season stage & 0.9 & 118 \\
\hline
\end{tabular}

\subsection{Statistics}

All the data were analyzed in GENSTAT 6.0 and means were separated using the Fisher's Least Significant difference (LSD) method.

\section{Results and Discussion}

\subsection{Cabbage Yield at Kasinthula and Masenjere}

Irrigation frequency significantly influenced weight of marketable heads at both sites $(\mathrm{P}<0.05)$. At Kasinthula (KAS) and Masenjere (MAS), F1 resulted in highest yield of 32.9 and $23.0 \mathrm{t} \mathrm{ha}^{-1}$ in 2006 and 2007 seasons (Figure 1). There was a 50\% and 25\% reduction in yield in 2007 at Kasinthula and Masenjere research sites. In both years, yields were four to five times higher at Masenjere than Kasinthula. Also, number of marketable heads at Masenjere was two to three times higher compared with that of Kasinthula. The results show that the Giant Drumhead variety of cabbage favours Masenjere and may not be suitable for Kasinthula.

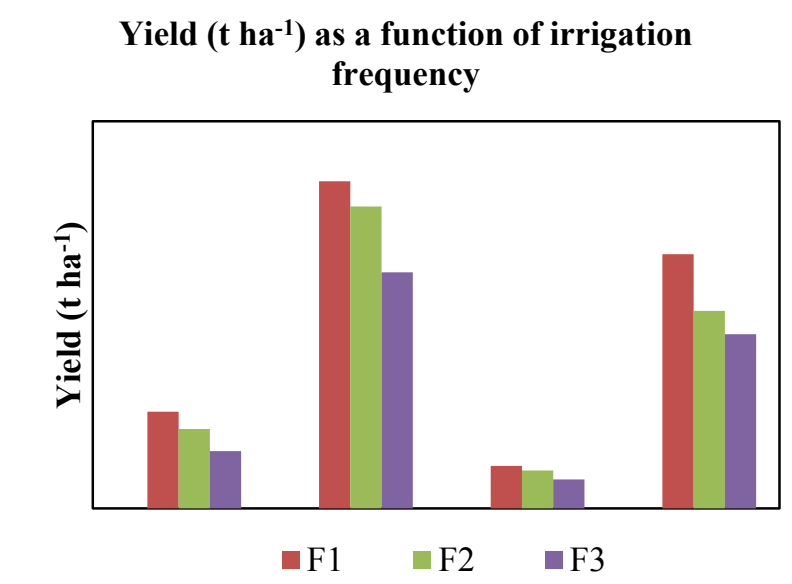

Figure 1. Yield $\left(\mathrm{t} \mathrm{ha}^{-1}\right)$ as a function of irrigation frequency

However, there were no significant differences in yields and number of marketable heads at Masenjere in both years between the three irrigation frequencies (Figure 2). This suggests that farmers faced with dwindling water resources farmers could opt for irrigation frequency F3 where $202 \mathrm{~mm}$ of water was applied to cabbage. Approximately 508 and 306 mm of water were applied in irrigation frequencies F1 and F2. F3 offers the growers a rational basis realizing reasonable yield while saving water. Where a farmer has ample water resources for the entire season, the F3 would still be employed but with adjustments on the amounts of water to be applied per season. F3 present an opportunity for introducing deficit irrigation in cabbage at Kasinthula and Masenjere. It was noted that average cabbage evapotranspiration for Kasinthula and Masenjere was $393 \mathrm{~mm}$ and was exceeded by F1 and F2. F3 did not meet the cabbage water requirement. 


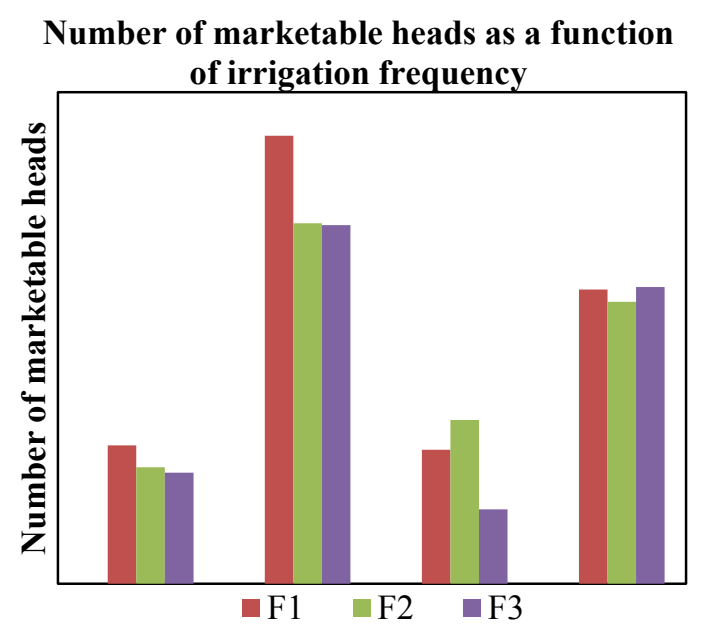

Figure 2. Number of marketable heads as function of irrigation frequency

The results agree with the findings of several researchers (Kleinhenz \& Radovich, 2003; Radovich, 2004; Radovich et al., 2004) who documented the effect of irrigation timing on head development and weights on cabbage. They concluded that head size and weight were greatest in cabbage receiving irrigation during head development. In their studies, the independent and interactive effects of year and irrigation treatment were largely explained by the proportion of crop evapotranspiration replaced during head development. The yields obtained in Masenjere are similar to those reported by Imtiyaz et al. (2000) in field studies in Botswana where cabbage yielded as high as $71.65 \mathrm{t} \mathrm{ha}^{-1}$. The cabbage yields at Kasinthula, despite receiving similar irrigation management treatments, suggest that the variety Giant drumhead is not suitable for the area.

\subsection{Water Use Efficiency (WUE) and Productivity (WP) of Cabbage}

WUE was significantly different across irrigation frequencies $(\mathrm{P}<0.05)$ at Kasinthula only in both years (Table 3$)$. WUE peaked in F1 to 83.6 and $57.5 \mathrm{~kg} \mathrm{ha}^{-1} \mathrm{~mm}^{-1}$ in 2006 and 2007 while lowest values were noted using F3 resulting in WUE of 57.9 and $39.4 \mathrm{~kg} \mathrm{ha}^{-1} \mathrm{~mm}^{-1}$. WUEs at Masenjere were four to five times those obtained at Kasinthula research site probably due to high evaporative demand at Kasinthula compared with Masenjere site (Barak, 1986).

Table 3. Effects of irrigation frequency on water-use efficiency $\left(\mathrm{kg} \mathrm{ha}^{-1} \mathrm{~mm}^{-1}\right)$

\begin{tabular}{|c|c|c|c|c|}
\hline \multirow{2}{*}{$\begin{array}{l}{ }^{\text {"Irrigation }} \\
\text { frequency }\end{array}$} & \multicolumn{2}{|c|}{2006} & \multicolumn{2}{|c|}{2007} \\
\hline & Kasinthula & Masenjere & Kasinthula & Masenjere \\
\hline $\mathrm{F} 1$ & $38.1 \mathrm{a}$ & $129.1 \mathrm{a}$ & 16.4 & 98.6 \\
\hline F2 & $31.3 \mathrm{~b}$ & $119.0 \mathrm{a}$ & 14.7 & 76.6 \\
\hline F3 & $22.7 \mathrm{c}$ & $93.1 \mathrm{~b}$ & 11.2 & 67.5 \\
\hline${ }^{+} \mathrm{LSD}_{0.05}$ & 4.7 & 15.0 & 4.6 & 13.9 \\
\hline${ }^{\dagger} \mathrm{CV}(\%)$ & 17.3 & 14.8 & 15 & 12.8 \\
\hline${ }^{\S}$ Significance & * & NS & $*$ & NS \\
\hline
\end{tabular}

${ }^{\top}$ 1-Irrigated twice a week, F2 - Irrigated once a week and F3-Irrigated once a fortnight.

*Least significant difference at $\alpha=0.05$.

${ }^{\dagger}$ Coefficient of variation.

${ }^{\S} \mathrm{NS}, *$ mean not significant and significant at $\alpha=0.05$.

Water productivity was significantly different across irrigation frequency $(\mathrm{P}<0.05) . \mathrm{F}_{3}$ resulted in the highest WP of 11.8 and $7.4 \mathrm{~kg} \mathrm{~m}^{-3}$ in 2006 and 2007, respectively. The lowest WP of 6.7 and $5.2 \mathrm{~kg} \mathrm{~m}^{-3}$ were observed in $\mathrm{F}_{1}$ in the two years. The results on WP show when faced with competing water needs in irrigated crop production then 
longer irrigation schedules are preferable. Our results on WP in vegetables agree with those obtained by Pachpute (2010) who reported water productivity of $12.1 \mathrm{~kg} \mathrm{~m}^{-3}$ in cucumber using pitcher irrigation and water conserving technologies such as manure application and mulching in neighboring Tanzania. The WP values also fall within the ranges reported by Molden et al. (2010) for vegetable crops. Comparing all the irrigation frequencies, $\mathrm{F}_{3}$ turns out to be the most effective water saving irrigation frequency suggesting that in the face of competing water needs and dwindling water resources, the longer duration $\mathrm{F}_{3}$ irrigation frequency is preferred to shorter duration ones.

Table 4. Effects of irrigation frequency on water productivity $\left(\mathrm{kg} \mathrm{m}^{-3}\right)$

\begin{tabular}{lcccc}
\hline \multirow{2}{*}{$\begin{array}{l}\text { Irrigation } \\
\text { frequency }\end{array}$} & \multicolumn{2}{c}{2006} & \multicolumn{3}{c}{2007} \\
\cline { 2 - 5 } & Kasinthula & Masenjere & Kasinthula & Masenjere \\
\hline $\mathrm{F} 1$ & $3.4 \mathrm{~b}$ & $10.0 \mathrm{a}$ & 3.2 & 7.2 \\
$\mathrm{~F} 2$ & $3.7 \mathrm{ab}$ & $13.8 \mathrm{~b}$ & 5.2 & 8.9 \\
$\mathrm{~F} 3$ & $4.4 \mathrm{a}$ & $18.1 \mathrm{c}$ & 2.9 & 11.8 \\
\hline${ }^{*} \mathrm{LSD}_{0.05}$ & 1 & 3 & 2.5 & 4.3 \\
${ }^{\dagger} \mathrm{CV}(\%)$ & 30.2 & 21 & 13.3 & 21.1 \\
${ }^{\S}$ Significance & $\mathrm{NS}$ & $*$ & $\mathrm{NS}$ & $*$ \\
\hline
\end{tabular}

${ }^{\mathrm{F}} \mathrm{F}$ 1-Irrigated twice a week, F2 - Irrigated once a week and F3-Irrigated once a fortnight.

${ }^{*}$ Least significant difference at $\alpha=0.05$.

${ }^{\dagger}$ Coefficient of variation.

${ }^{\S} \mathrm{NS}, *$ mean not significant and significant at $\alpha=0.05$.

\section{Conclusion}

The study sought to determine the effect of irrigation frequency on WUE, WP and yield of cabbage. As confirmed in the results, we conclude that irrigation frequency has a significant bearing on yield, WUE and WP of cabbage. We also note that research site resulted in remarkable differences in the crop response functions under study. Thus, we suggest further investigations using several cabbage varieties at both Kasinthula and Masenjere research sites before passing on the recommendations to farmers in order to obtain more consistent results. However, some clear trends were observed. First, F1 resulted in highest yield and WUE in both seasons while F3 yielded lowest. The reverse was true for WP. Comparing all the irrigation frequencies, F3 turns out to be the most effective water saving irrigation frequency suggesting that in the face of competing water needs and dwindling water resources, the longer duration F3 irrigation frequency is preferred to the shorter duration ones. Where water is considered ample, F1 is recommended. Resources permitting, a research attempt on raising cabbage under both controlled greenhouse and field conditions should be made because field studies alone consistently showed low cabbage yields at Kasinthula despite good irrigation management.

\section{Acknowledgements}

The author acknowledges with thanks the funding from the Malawi Government, Ministry of Agriculture and Food Security. The author acknowledges constructive comments of two anonymous reviewers, the input of Dr. Fandika at the start of the project and the technical help of Messers W. Chafutsa, H. Mapwesera, G. Mafunga and Mrs Chiipanthenga. The author is also grateful to Mr. Sonjera of Bvumbwe Agricultural Research Station in conducting all soil physical and chemical analyses.

\section{References}

Allen, R. G., Pereira, L. S., Raes, D., \& Smith, M. (1998). Crop evapotranspiration guidelines for computing crop water requirements. FAO Irrigation and Drainage Paper 56. Food and Agriculture Organization of the United Nations, Rome.

Barak, E. (1986). Service Training Irrigation Research project. Department of Agricultural research Services, Ministry of Agriculture, Malawi.

Chilimba, A. D. C. (1990). Salinity and sodicity monitoring activities in low lying areas. Paper Presented at Soils and Agricultural Engineering Group Project Meeting, Malawi Government, 1-4 October, 1990. 
de Fraiture, C., \& Wichelns, D. (2010). Satisfying future water demands for agriculture. Agricicultural Water Management, 97(4), 502-511. http://dx.doi.org/10.1016/j.agwat.2009.08.008

de Fraiture, C., Molden, D., \& Wichelns, D. (2010). Investing in water for food, ecosystems, and livelihoods: An overview of the comprehensive assessment of water management in agriculture. Agricicultural Water Management, 97(4), 495-501. http://dx.doi.org/10.1016/j.agwat.2009.08.015

Doorenbos, J., \& Pruitt, W. O. (1977). Guidelines for predicting crop water requirements. FAO Irrigation and Drainage Paper No. 24, FAO, Rome.

Doorenbos, J., \& Kassam, A. H. (1979). Yield Response to Water. FAO Irrigation and Drainage paper no. 33.

Doorenbos, J., \& Kassam, A. H. (1986). Yield Response to Water. Food and Agriculture Organization.

Fandika, I. R., Kadyampakeni, D., Bottomani, C., \& Kakhiwa, H. (2007). Comparative response of varied irrigated maize to organic and inorganic fertilizer application. Physics and Chemistry of the Earth, Parts A/B/C 32(15-18), 1107-1116. http://dx.doi.org/10.1016/j.pce.2007.07.025

FAO. (2000). Crops and Drops. Land Water Management Division, FAO, Rome, Italy.

Hess T. M., \& Molatakgosi, G. (2009). Irrigation management practices of cabbage farmers in Botswana using saline groundwater. Agricicultural Water Management, 96(2), 226-232. http://dx.doi.org/10.1016/j.agwat.2008.08.005

Imtiyaz, M., Mgadla, N. P., Chepete, B., Manase, S. K. (2000). Response of six vegetable crops to irrigation $\begin{array}{llll}\text { schedules. } \quad \text { Agricicultural } & \text { Water }\end{array}$ http://dx.doi.org/10.1016/S0378-3774(99)00105-5

Kirda, C. (2002). Deficit irrigation scheduling based on plant growth stages showing water stress tolerance. Deficit Irrigation Practice (pp. 3-10). Water Report 22. FAO, Rome.

Kleinhenz, M. D., \& Radovich, T. J. K. (2003). Rapid, accurate, in-field prediction of cabbage marketable yield. Acta Horticulturae, 628, 111-118.

Lovelli, S., Perniola, M., Ferrara, A., \& Di Tommaso, T. (2007). Yield response factor to water (Ky) and water use efficiency of Carthamus tinctorius L. and Solanum melongena L. Agricicultural Water Management, 92(1-2), 73-80. http://dx.doi.org/10.1016/j.agwat.2007.05.005

Molden, D., Oweis, T., Steduto, P., Bindraban, P., Hanjra, M. A., \& Kijne, J. (2010). Improving agricultural water productivity: Between optimism and caution. Agricultural Water Management, 97(4), 528-535. http://dx.doi.org/10.1016/j.agwat.2009.03.023

Pachpute, J. S. (2010). A package of water management practices for sustainable growth and improved production of vegetable crop in labour and water scarce Sub-Saharan Africa. Agricultural Water Management, 97(9), 1251-1258. http://dx.doi.org/10.1016/j.agwat.2009.11.009

Poynton, R. J. (1995). Tree planting in Southern Africa. Report to the Southern African Commission for the Conservation and Utilization of the Soil (SARCCUS).

Radovich, T. J. K. (2004). Effects of abiotic growth factors on glucosinolate Levels, sensory quality and yield components in cabbage (Brassica oleracea group capitata). $\mathrm{PhD}$ dissertation, Ohio State University.

Radovich, T. J. K., Kleinhenz, M. D., Delwiche, J. F., \& Liggett, R. E. (2004). Triangle tests indicate that irrigation timing affects fresh cabbage sensory quality. Food Quality and Preference, 15, 471-476. http://dx.doi.org/10.1016/j.bbr.2011.03.031

Rockstrom, J., Barron, J., \& Fox, P. (2002). Rainwater management for increased productivity among small-holder farmers in drought prone environments. Physics and Chemistry of the Earth, Parts A/B/C 27(11-22), 949-959. http://dx.doi.org/10.1016/S1474-7065(02)00098-0

Smith, M. (2000). Optimizing crop production and crop water requirement under reduced water supply. FAO Irrigation and Drainage Paper, FAO, Rome.

\section{Copyrights}

Copyright for this article is retained by the author(s), with first publication rights granted to the journal.

This is an open-access article distributed under the terms and conditions of the Creative Commons Attribution license (http://creativecommons.org/licenses/by/3.0/). 